This item was submitted to Loughborough's Research Repository by the author.

Items in Figshare are protected by copyright, with all rights reserved, unless otherwise indicated.

\title{
How did material culture matter in the Khrushchev-Era USSR? Everyday aesthetics and the socialist culture of things
}

PLEASE CITE THE PUBLISHED VERSION

https://www.vandenhoeck-ruprecht-verlage.com/themen-entdecken/geschichte/geschichte-derneuzeit/40545/zeitgeschichte-der-dinge

\section{PUBLISHER}

Böhlau Verlag

\section{VERSION}

AM (Accepted Manuscript)

\section{PUBLISHER STATEMENT}

This paper was accepted for publication in the book Zeitgeschichte der Dinge: Spurensuchen in der materiellen Kultur der DDR and the definitive published version is available at https://www.vandenhoeckruprecht-verlage.com/themen-entdecken/geschichte/geschichte-der-neuzeit/40545/zeitgeschichte-der-dinge.

\section{LICENCE}

CC BY-NC-ND 4.0

\section{REPOSITORY RECORD}

Reid, Susan. 2019. "How Did Material Culture Matter in the Khrushchev-era USSR? Everyday Aesthetics and the Socialist Culture of Things". figshare. https://hdl.handle.net/2134/35052. 


\author{
Susan E. Reid
}

\title{
How did Material Culture Matter in the Khrushchev-Era USSR? Everyday Aesthetics and the Socialist Culture of Things
}

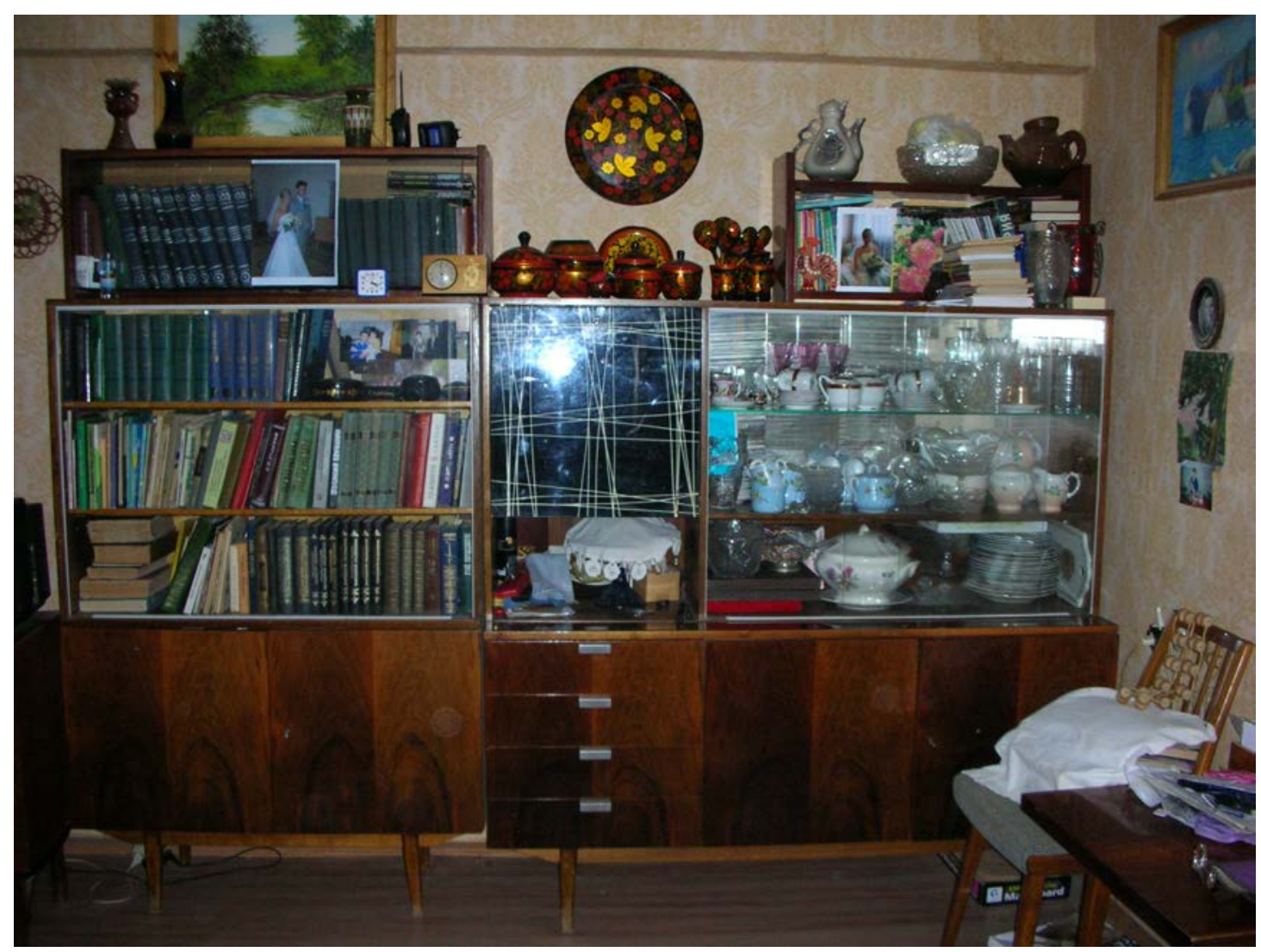

Fig. 1. A glazed china cabinet and bookcase from the 1960s still present in a khrushchevka interior in Kaluga in 2005. Photo for Everyday Aesthetics, 2005. Copyright: Susan E. Reid

How did matter matter in the Soviet socialist past? And why should it matter today, to historians of the Soviet experiment? What are the benefits of engaging in the "archaeology of state socialism," attempting, that is, to interpret and understand Soviet society through its artefacts, material traces, and spaces? ${ }^{1}$

This paper focuses on the material culture of private, domestic space in the USSR after Stalin, in the late 1950 s to the 1970s, a period which saw rapid and radical transformations in the material environment of everyday life. Arguably one of the most significant developments of this period was the new priority that the party-state and

\footnotetext{
1 Victor Buchli, An Archaeology of Socialism (Oxford: Berg, 1999).
} 
centrally planned economy gave to improving mass living standards and addressing the chronic problem of housing. A campaign launched in 1957 by Nikita Khrushchev set in train the mass industrialized construction of separate apartments in large self-contained mikroraiony (microdistricts), to which millions of "new settlers" (novosely) relocated over the next decade. ${ }^{2}$ I will outline some ways in which the study of material environments, objects, collections and arrangements of things can help us access aspects of the vernacular experience of this late Soviet wave of modernization which other methods and sources alone cannot reach, helping us to investigate historical changes in consciousness, sense of self, and interpersonal relationships.

The historiography of the Khrushchev Thaw, until recently largely based on textual sources, has been written primarily in terms of the agency and views of the intelligentsia and party elite. In the rhetoric of the Communist Party of the Soviet Union, and in the discourses of Soviet architects, designers and aesthetic philosophers, material culture was invested with ideological significance and pedagogical effectiveness in preparing the material and social premises for the transition to full communism. But this is only part of the story. A material culture approach to history can go beyond examining authoritative discourses, policies, conditions of production and intended effects (for example of the new state housing), to consider how the material effects of power-such as the spaces and things produced as a result of party decrees and economic planning and invested with authoritative intentions-were used, adapted, appropriated, combined, misused or repurposed, according to the needs, desires and tastes of inhabitants and users. ${ }^{3}$ Material as well as visual sources can help us to address the lack of a written record in relation to everyday history and the lives of "ordinary people," enabling the study of historical subjects and areas of life that have been "hidden from textual history". ${ }^{4}$ Thus the "material turn" further advances the shift away from writing "history from above" - as if history was made only by those at the top, with power and authority - towards "history

2 “O razvitii zhilishchnogo stroitel'stva v SSSR,” 31 July 1957, Sobranie postanovlenii pravitel'stva SSSR, no. 9 (1957); Mark B. Smith, Property of Communists: The Urban Housing Program from Stalin to Khrushchev (Dekalb: Northern Illinois University Press, 2010).

${ }^{3}$ Michel de Certeau, The Practice of Everyday Life (Berkeley: University of California Press 1984); John Fiske, Understanding Popular Culture (London: Routledge, 1989); Nelly Oudshoorn and Trevor Pinch, eds, How Users Matter: the Co-Construction of Users and Technology (Cambridge, Mass.: MIT Press, 2003).

${ }^{4}$ Sheila Rowbotham, Hidden from History: 300 Years of Women's Oppression and the Fight Against It (London: Pluto Press, 1975); Catherine Armstrong, Using Non-Textual Sources: A Historian's Guide (London: Bloomsbury 2016), 98; Ludmilla Jordanova, The Look of the Past: Visual and Material Evidence in Historical Practice (Cambridge, UK: Cambridge University Press, 2012). 
from below," which seeks out the agency, experience and subjectivity of "ordinary people": makers, users and consumers. How were artefacts and environments, which were designed as expressions and instruments of power and as agents of regime-led socialist modernization, consumed, repurposed, misused, or rejected?

This chapter will first set out the authoritative, ideological-philosophical discourses around the meaning and aesthetics of things. ${ }^{5}$ Second, I will turn to the view from "below," from the perspective of users and everyday practices. This division is a contingent analytical structuring device rather than an impermeable divide; the uses and meanings of things, and even their material qualities themselves, were constructed in the interaction between these factors. ${ }^{6}$ In focusing on material culture, I aim to bring together into the same frame the "macropowers affecting changing state fortunes," and "the micropowers at work in everyday life".7 Relations between these two perspectives from "above" and "below," theory and practice, macro and micro - were negotiated in people's homes, decorating practices, and domestic consumption and everyday interactions with spaces and things. In socialist modernity, no less than in the consumer culture of the capitalist West, the acquisition, arrangement, repair, and ridding of domestic furnishings and displays played a crucial role in the production and maintenance of self-identity, even in over-determined surroundings which represented the agency of others.

The paper draws on a larger project in which I explore the agency, choices and experience of "new settlers" (as those moving to the new housing regions were called in the press), in regard to homemaking and decorating, consumption and display, and how they account for these. Over seventy semi-structured oral history interviews were conducted between 2004 and 2007, with individuals - mostly women born between the 1920s and early 1940s - who had moved to new, "khrushchevki" separate apartments in

\footnotetext{
${ }^{5}$ Susan E. Reid, "Cold War in the Kitchen: Gender and the De-Stalinization of Consumer Taste in the Soviet Union under Khrushchev," Slavic Review 61, no. 2 (2002): 211-52.

${ }^{6}$ Ekaterina Gerasimova and Sofia Chuikina, "Obshchestvo remonta," Neprikosnovennyi zapas, no. 34 (2004); Sergei Alasheev, "On a Particular Kind of Love and the Specificity of Soviet Production," in Glen Adamson, The Craft Reader (Oxford: Berg, 2010), 287-96; Susan E. Reid, "Makeshift Modernity: DIY, Craft and the Virtuous Homemaker in New Soviet Housing of the 1960s," International Journal for History, Culture, and Modernity 2, no. 2 (2014): 87-124; Alexei Yurchak, Everything Was Forever, Until It Was No More: The Last Soviet Generation (Princeton, NJ: Princeton U.P. 2006).

7 Buchli, Archaeology, 3; Daniel Miller, "Appropriating the State on the Council Estate," Man 23 (1988), 353-72; idem, Material Cultures: Why Some Things Matter (University of Chicago Press, 1998); idem, "Accommodating," in Colin Painter, ed., Contemporary Art and the Home (Oxford: Berg, 2002), 115-30.
} 
a range of cities across the former Soviet Union during the $1960 \mathrm{~s}^{8}$ The interviews were conducted in their homes amidst their accumulated possessions and displays. While oral history was a key part of my methodology, ${ }^{9}$ a reliance solely on verbal accounts tends to privilege conscious intentions and already narrativized memories over motives and emotions that may be harder to put into words, or which may even be suppressed from conscious thought. ${ }^{10}$ If we are interested in questions about subjectivity and emotional experience and in the effects of historical changes on individuals' sense of self, oral narratives have some limitations because self-identity and a changing self and self-other relations are not only worked out and articulated in verbal narratives; they are also objectified and produced in relations with things, material environments and practices. This is where material culture history comes into its own, requiring an engagement with visual and sensory ethnography. ${ }^{11}$ As part of the data production, the objects and displays formed the focus of the conversations and were photographed. By attending to material self-presentation and aesthetic practices of display in the late Soviet home, in combination with listening to how the authors of these displays account for them in oral narratives, the project seeks to open up some of the complexities and contradictions of how historical subjects experienced this period of rapid but uneven state-led modernization, how they accommodated and made sense of or mitigated these changes, and how they negotiated between plural and heterogeneous norms in "making themselves at home". Objects and material environments do not simply "reflect" historical processes as mere effects or traces of historical events, but are active agents, "tools through which people shape their lives," as Leora Auslander has put it. They "create social positions and even (some argue) the self itself".12 Domestic material culture in conjunction with oral narratives, may serve as a source through which we can

8 "Everyday Aesthetics in the Modern Soviet Flat," funded by The Leverhulme Trust (2004-07) and AHRC (2008). Interviews were conducted in St Petersburg, Kaluga, Kazan', Samara, Kovdor, Apatity, and Tartu.

9 The narrative nature of oral history responses is particularly significant (and problematic) because of the onus placed on narrativization of the self both in theories of the modern self and in consumer culture, e.g. Anthony Giddens, Modernity and SelfIdentity: Self and Society in the Late Modern Age (Cambridge: Polity Press, 1991), 80; Dan Slater, Consumer Culture and Modernity (Cambridge: Polity Press, 1997), 91-2.

${ }^{10}$ Alyssa Grossman, "Forgotten Domestic Objects" Home Cultures 12 no. 3 (2015): 291310; Rachel Hurdley, "Dismantling Mantelpieces: Narrating Identities and Materializing Culture in the Home," Sociology 40/4 (2006): 721-2 of 717-33; Nicolette Makovicky, "Closet and Cabinet: Clutter Cosmology," Home Cultures 4/3 (2007): 290 of 287-310.

11 Sarah Pink, Doing Sensory Ethnography, 2nd edn (Los Angeles: Sage, 2013).

12 Leora Auslander, "Beyond Words," The American Historical Review 110 (2005), No. 4: 1016-7 of 1015-45; Introduction, in Anne Gerritsen and Giorgio Riello, eds, Writing Material Culture History (London: Bloomsbury, 2015), 2; Judy Attfield, Wild Things: The Material Culture of Everyday Life (Oxford: Berg, 2000). 
try to understand historical subjectivity. As Auslander also notes, "material culture consists not only of things but also of the meanings, values, associations, and memories they hold for people." 13 The reluctance of modern historians to make use of material or visual sources has been underpinned by a suspicion that, requiring interpretation, they were too subjective and unverifiable. Now precisely the polysemy, subjectivity, and sensual qualities of things, and their function as mnemonics, are made productive for a new history that recognizes that the subjective, experience, sensory are important parts of human life and should, therefore, matter to historians. ${ }^{14}$

\section{Producing a socialist material culture: the view "from above"}

The power of a transformed material environment to engineer social transformation was an article of faith in Bolshevik Russia after the Revolution. In this regard it shared in the widespread utopian impulse of the international Modern Movement between the wars, but the instrumentalization of the material environment as a socializing force in the new USSR also had specific philosophical premises in Marx's materialist explanation of historical change. According to Marx, "the transformation of any society should be revealed by the changing relations of persons to objects within it." 15 Marxist-Leninist teleology ascribed an important relationship between material culture and the construction of Communism and of its ideal subject, the "new Soviet person".

The Bolshevik revolution of 1917 seemed to offer conditions to break radically with the past and remake the world anew, according to rational, materialist and socialist principles. Avant-garde artists and cultural theorists around the magazine LEF (Left Front of the Arts), such as Boris Kushner, Boris Arvatov and Vladimir Tatlin, threw

${ }^{13}$ Auslander, "Beyond Words," 1016-7; Marius Kwint, Christopher Breward, Jeremy Aynsley, eds, Material Memories: Design and Evocation (Oxford: Berg, 1999); Mihaly Csikszentmihalyi and Eugene Rocheberg-Halton, The Meaning of Things (Cambridge, UK: Cambridge University Press, 1981).

${ }^{14}$ Auslander, "Beyond Words," 1016-7 of 1015-45; Steven Lubar and W. David Kingery, History from Things: Essays on Material Culture (Washington, D.C.: Smithsonian Institution, 1993); Karen Harvey, ed., History and Material Culture: a Student's Guide to Approaching Alternative Sources (London: Routledge, 2009). Examples of the sensory turn in history and convergence of everyday history with anthropology include: Mathiew P. Romaniello and Tricia Starks, eds, Russian History through the Senses (London: Bloomsbury, 2016); Choi Chatterjee et al, eds, Everyday Life in Russia Past and Present (Bloomington, Ind.: Indiana University Press, 2015).

15 Jean and John Comaroff, "Goodly Beasts, Beastly Goods," American Ethnologist 17, no. 2 (1990): 196 of 195-216 (cited by Patico, Consumption and Social Change, 2); Karl Marx, Capital: A Critique of Political Economy vol. 1 trans. B. Fowkes (New York: Penguin Books 1990 [1887]); Jennifer Patico, Consumption and Social Change in a Post-Soviet Middle Class (Stanford University Press, 2008), 2. 
themselves into the transformative project of creating a new society and a new type of human being through material means: by seeking to define a new, socialist material culture and socialist object. ${ }^{16}$ The task of artists, architects and other specialists in the material environment, according to this "Productivist" platform, was to transform the material culture of everyday life (byt), and to define the nature of "non-market objects," as distinct from commodities. The restructuring of subject-object relations under socialism was, in part, a design problem, for the desired non-fetishistic relations with things were to be "organized" by the formal and material qualities of the objects themselves. ${ }^{17} \mathrm{New}$ terms were coined for the analysis of social cultural relations with things, such as "material installation" (material'naia ustanovka), the "culture of the thing" (veshchevaia kul'tura), as well as "material culture" (material'naia kul'tura). ${ }^{18}$

This radically transformative programme, linking societal and psychological renovation to material revolution, was suppressed under Stalin. But after his death in 1953, utopian aspirations for the progressive social role of material culture were revived and received particular attention in the context of public discussions of the draft Third Party Programme (dubbed the "Communist Manifesto of the present day") between 1959 and $1961 .{ }^{19}$ Revisiting the Productivist ideas of the 1920s, philosophers, utopian architects and authors of popular advice ascribed considerable ideological and moral significance to the material environment of everyday life as a means to direct behaviour and (re)structure consciousness and social relations; it was a powerful agent of socialist modernization, of social and psychological transformation. ${ }^{20}$ By the same coin, however, an unreconstructed material environment could also potentially obstruct progress and perpetuate throwbacks to the pre-revolutionary past.

Specialist discourses about the fashioning of things and spaces were informed by renewed attention, in the late 1950s-60s, to Marx's early writings (published in a new edition in 1956) on the role of material making in becoming truly human. In his Economic-Philosophic Manuscripts, Marx had paid attention to questions of aesthetic

${ }^{16}$ Christina Kiaer, Imagine No Possessions: The Socialist Objects of Russian Constructivism (MIT, Cambridge, MA. 2005); Margaret Rose, Marx's Lost Aesthetic (Cambridge: Cambridge University Press, 1985).

${ }^{17}$ Boris Arvatov, "Everyday Life and the Culture of the Thing," October, 81 (1997), 119-28. ${ }_{18}$ Selim Khan-Magamedov, Arkhitektura sovetskogo avant-garda.

http://www.alyoshin.ru/Files/publika/khan archi/khan archi 1 073.html. Last accessed 06/09/2018.

${ }^{19}$ Jerome M. Gilison, The Soviet Image of Utopia (Baltimore: Johns Hopkins University Press, 1975), 9.

${ }^{20}$ E.g. Aleksandr Saltykov, "Pervyi vsesoiuznyi s'ezd sovetskikh khudozhnikov," Iskusstvo, no. 3 (1957): 3-36. 
sensibilities and beauty. While animals might build dwellings for themselves, they only produced to satisfy immediate needs, whereas "man fashions things according to the laws of beauty". ${ }^{21}$ The emphasis on the aesthetics of the everyday material environment was central to Khrushchev-era utopianism. ${ }^{22}$ Numerous works were published with titles such as On Beauty, or Create the World According to the Laws of Beauty. They made proclamations such as "Communism is not only the abundance of material blessings. It is also the realm of the beautiful"; ${ }^{23}$ and, "Communism in the present period enters the world stage not only as a new social-political order but also as a new aesthetic." 24 The transition to full communism demanded that all aspects of Soviet life must become more beautiful and that each Soviet person should develop heightened aesthetic sensibility. ${ }^{25}$ In the cultivation of a new aesthetically conscious Soviet person an important role was assigned also to the aesthetics of everyday life and domestic material culture. ${ }^{26} \mathrm{In}$ accordance with Hegelian dialects of subject and object, at the same time as material things objectified his feelings and worldview, they also produced, or at least conditioned, them. ${ }^{27}$

${ }^{21}$ Karl Marx, "Economic and Philosophical Manuscripts," in David McLellan, Karl Marx: Selected Writings (Oxford University Press, 1977), 82; Karl Marx and Friedrich Engels, Iz rannykh proizvedenii, (Moscow, 1956); Saltykov, "Pervyi vsesoiuznyi s'ezd". According to Khrushchev, nothing was more beautiful than unalienated labour: Nikita S. Khrushchev, "Sovetskoe iskusstvo obogashchaet dukhobnuiu sokrovishchnitsu vsego chelovechestva," in idem, Vysokoe prizvanie literatury i iskusstva (Moscow: Pravda, 1963): 155, 160-1.

22 Susan E. Reid, “Destalinization and Taste, 1953-163," Journal of Design History 10, no. 2 (1997): 177-202; James Scanlan, Marxism in the USSR (Cornell University Press, 1985): 293; Andrei Burov, Esteticheskaia sushchnost' iskusstva (Moscow: Iskusstvo, 1956); Semen Rappoport, Tvorit' mir po zakonam krasoty (Sovetskii kompozitor, 1962); Nina Dmitrieva, O prekrasnom (Moscow: Iskusstvo, 1960).

${ }^{23}$ Rappoport, Tvorit' mir, 8, 64-6; Editorial, "Istoricheskii s"ezd stroitelei kommunizma," Iskusstvo, 1961 no. 11: 2-8; Editorial "Kommunizm i iskusstvo," Kommunist no. 8 (1961): 3-10.

24 "Kommunizm v nastoiashchii istoricheskii period vystupaet na mirovoi arene ne tol'ko kak novyi sotsial'no politicheskoi stroi, no i kak novaia estetika." D. Kozlov, "Kommunizm i iskusstvo," GARF f. 9547 (Znanie), op.1, d. 1185: "Stenog. seminara-soveshchaniia po voprosam propagandy literatury i iskusstva, 17/10/1960," ll.11-32.

25 Viktor Vanslov, "Iskusstvo i vsestoronnee razvitie lichnosti," Iskusstvo, no. 3 (1962): 26; Vl. Zimenko, "Chelovek, kharakter, obraz," Iskusstvo no. 1 (1962): 5-6; V. Ustinov, Ob esteticheskom vospitanii (Leningrad: Lenizdat, 1961); Editorial, "Istoricheskii s"ezd stroitelei kommunizma," Iskusstvo, no. 11 (1961): 2-8; Editorial "Aktual'nye voprosy estetiki v svete novoi Programmy KPSS," Voprosy filosofii, no. 9 (1962): 3-14; "Programme of the CPSU" (1961) 249, 255-6.

${ }^{26}$ N. Parsadanov, "Programma KPSS i zadachi sovetskogo iskusstva," Tvorchestvo, no. 11 (1961): 1-4; Iu. Filatov, "Veshchi, sovremennost', zhivopis'," Zvezda, no. 2 (1961): 176-9.

27 "Pervyi vsesouznyi s"ezd' sovetskikh khudozhnikov," Iskusstvo no. 3 (1957): 14-16 of 336; Rose, Marx's Lost Aesthetic; K. Marks [Marx], F. Engels, Ob iskusstve (Moscow: 1957) v. 1, 141; Dmitrieva, O prekrasnom. 
As millions of people moved into new flats and began to furnish them with a mix of old and new things, the aesthetics of everyday life was recognized as a matter of crucial significance for the success of the Soviet project; the new domestic interior was a site for education of the new person in the final push towards communism. Everyday, utilitarian objects, while meeting everyday practical needs, were also tasked with the utopian, future-oriented mission of developing the all-sided individual, the new socialist subject. Thus the decoration of the new apartment must "raise the culture of the Soviet person, and take part in the upbringing of the constructors of communist society." 28 Architects, artists, and philosophers claimed that this gave them, as specialists on aesthetics, a vital role to play in determining standards of taste. Good design of exemplary modern furniture and decorative items for the new flats was vital, given the push to mass production both of new housing and of furniture; a fault in the prototype would be multiplied million-fold. ${ }^{29}$ Such arguments underpinned the birth of the Soviet discipline of design or Technical Aesthetics, whereby a new set of specialists aspired to set standards for mass production. ${ }^{30}$

But the furnishing and decoration of new flats was not only a problem of design and mass production but also one of mass consumption. And even the centrally planned command economy could not command consumption. ${ }^{31}$ Aesthetic specialists recognized that, for better or worse, their jurisdiction was limited behind the closed doors of individual apartments, where "the last word belongs to the occupant". ${ }^{32}$ This was a cause for anxiety. Would "new settlers" aspire to the same standards as those the intelligentsia experts and designers prescribed? Or would the new, separate flats call forth vestigial petit-bourgeois instincts, private property values, insatiable demand for consumer goods, and commodity fetishism?33 "The hypertrophy of interest in the individual dwelling is inclined to engender an antisocial, anti-communist mindset," warned one philosopher of

\footnotetext{
${ }^{28}$ Editorial, "Kommunizm i iskusstvo," 5-6.

${ }^{29}$ K. Zhukov, "Tekhnicheskaia estetika i oborudovanie kvartir," Tekhnicheskaia estetika, no. 2 (1964): 1 of 1-2.

${ }^{30}$ Susan E. Reid, "Khrushchev Modern: Agency and Modernization in the Soviet Home, Cahiers du Monde russe 47 (1), 227-268. On the foundation of the design institute VNIITE see Raymond Hutchings, Soviet Science, Technology, Design (Oxford: Oxford University Press, 1976).

31 Fuller argumentation in Reid, "Khrushchev Modern," 227-268; and Susan E. Reid, "Cold War Binaries and the Culture of Consumption in the Late Soviet Home," Journal of Historical Research in Marketing 8, no. 1 (2016): 17-43.

32 E.g. RGALI, f. 2329, op. 4, ed. khr. 1388, ll. 51-2 (N. Luppov, Stenog. sobraniia ... po obsuzhedenniu vystavki "Iskusstvo - v byt!" 6 June 1961); Irina Voeikova, "Vasha kvartira," Rabotnitsa, no. 9 (1962): 30.

33 Fuller argumentation in Reid, "Cold War in the Kitchen," 211-52.
} 
the material environment. ${ }^{34}$ Would-be Soviet consumers were admonished to consume "rationally," in moderation, and with taste, and were cautioned against irrational, "petitbourgeois" acquisitiveness and fetishism; things must be kept in their place as "slaves not masters". ${ }^{35}$ To ensure that citizens settling into new flats would make the right choices, exhibitions, magazines and television issued advice on good and bad taste in home decorating, and disseminated examples of ideal modern interiors furnished in a new rationalist, modern style developed in the late 1950s, dubbed the "Contemporary Style". A version of the international modernist aesthetic of the post-war period, the Contemporary Style called for simple lines and unadorned surfaces, for rational designs that facilitated serial, machine production and the use of man-made materials. ${ }^{36}$

Thus, in the early 1960s, material culture - especially that of the new, separate apartment - was ascribed a specific and vital role in preparing Soviet society for the transition to Communism, marked by the masses' accession to abundance and beauty. The neoMarxist, neo-Productivist utopian platform among Soviet philosophers and aestheticians in the Thaw, concerned with material culture and everyday aesthetics, was a significant intellectual development and provided the theoretical underpinning for the establishment of the Soviet design discipline in this period.

However, we cannot assume that "ordinary people" saw things in the same way, or that practice matched blueprint. Such a view, common to the "Totalitarian" school, has been much critiqued, not least because it denies any space for the agency of "ordinary people" and social forces. ${ }^{37}$ The meanings things held for users were not necessarily the same as those they held for designers, producers, economists, and ideologues. To what extent-if at all - did these authoritative, utopian, Marxist "meanings of things" pervade everyday relations with things in the "private" space of the home, where the specialists' purview was limited? How and to what extent did new settlers appropriate the new approved style into their homes and assimilate it to their sense of self? We turn now from topdown, authoritative discourses and the utopian, socially transformative intentions

${ }^{34}$ Cited by Iu. Gerchuk, "S tochki zreniia shestidesiatnika," Dekorativnoe iskusstvo SSSR (henceforth DI no. 7 (1991), 9; K. Kantor, "Veshchi i sotsial'nye otnosheniia," in Kantor, Krasota i pol'za (Moscow, 1967), 228 ff., with reference to a 1922 lecture by Boris Kushner, "Proizvodstvo kul'tury".

${ }^{35}$ Iu. Filonovich, "Veshchi - ne khoziaeva, a slugi!," Izvestiia, No. 163 (1959), 4; B. Brodskii, "Novyi byt i kamufliazh meshchanstva," DI SSSR, no. 8 (1963), 23-8; Reid, "Cold War in the Kitchen," 211-52.

${ }^{36}$ Iurii Gerchuk, "The Aesthetics of Everyday Life," in Susan E. Reid and David Crowley, eds, Style and Socialism: Modernity and Material Culture in Post-War Eastern Europe (Oxford/New York: Berg, 2000), 81-100.

37 E.g. Sheila Fitzpatrick, ed. Stalinism: New Directions (London and New York: Routledge 2000). 
invested in the built space of khrushchevki, to the perspective from "below," and the questions: "what did ordinary people do in practice" behind the closed doors of their new flats and how do they account for change?

\section{"Everyday Aesthetics"}

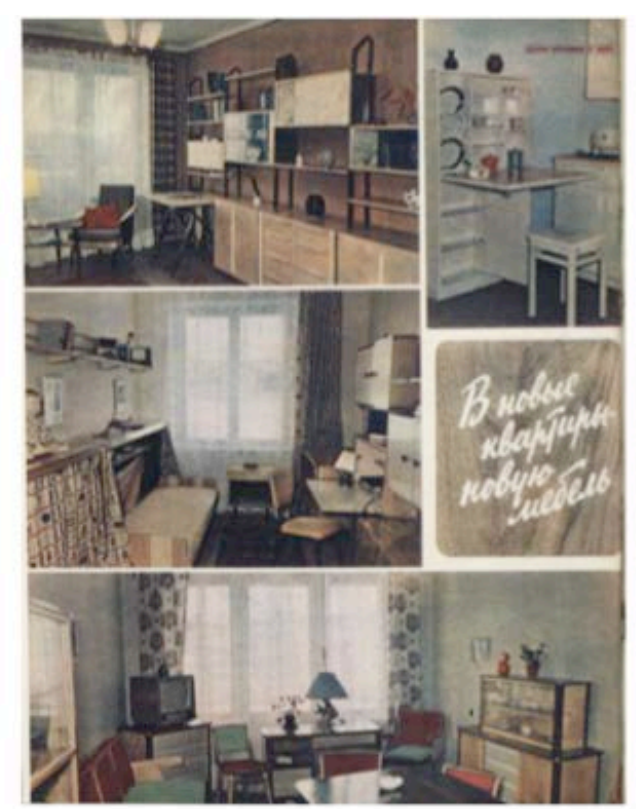

Fig. 2. "New Furniture for the New Flat," Ogonek, No. 11, 1959. Showing examples of new lightweight and convertible furniture designed for the new flats.

A central aim of the larger project on which this paper draws was to test how the "Soviet ideal home" was realized in practice; how actual historical subjects, rather than the abstractions imagined by planners and ideologues, made the standard spaces of new flats into home. What, if any, attention did they pay to the prescriptive discourses of good taste, rationality and modern beauty, exemplified by the Contemporary Style? Or did they operate with different criteria of order, beauty, and taste? Did they share the experts' concern with aesthetics and faith in the transformative agency of things? How did the material culture of domestic everyday life change in the 60s, what did it mean to "ordinary people," and what can it tell us about how they experienced the rapid modernization of the Khrushchev era? In this brief article there is only space for three 
examples of objects and arrangements that emerge from the interviews and interiors as especially salient: beds, rugs, and photographs as material objects. ${ }^{38}$

Beds and the modernization of the culture of sleep

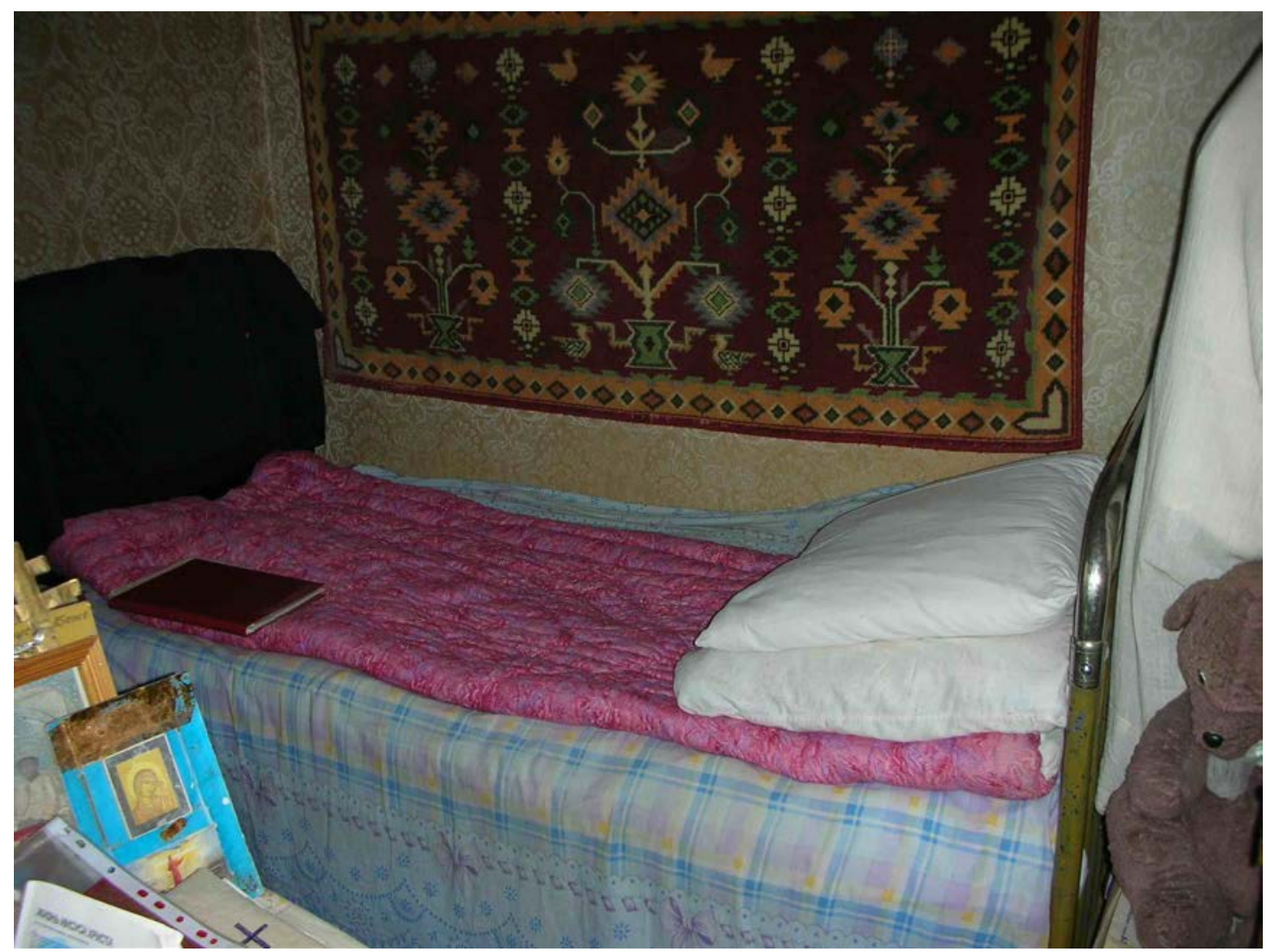

Fig. 3. Metal bedstead, Kaluga. Photo for Everyday Aesthetics, 2005. Copyright: Susan E.

Reid

Attitudes and practices were in the process of transformation in the course of the 1960s-

70s. New moralities of consumption began to contend with established dispositions. A shift from "filling essential needs" to a form of "modern consumption" can be examined in regard to one of the "essential" items of the home, as a place of rest: beds. ${ }^{39}$

Beds - metal bedsteads - were, in the 1950s, an item of furniture that one would expect to have for life, only replacing the mattress periodically. Even when informants say they brought "nothing" to the new apartment, they often make an exception for the bed. They

${ }^{38}$ For further discussion see: Susan E. Reid, "Everyday Aesthetics in the Khrushchev-Era Standard Apartment," Etnofoor 24, no. 2 (2012), 79-107; Susan E. Reid, "Kak obzhivalis' v pozdnesovetskoi modernosti" ["Making Oneself at Home in Late Soviet Modernity"] in A. Pinsky, ed., Posle Stalina: pozdnesovetskaia sub"ektivnost', 1953-1985 gg. [After Stalin: Subjectivity in the Late Soviet Union, 1953-1985] (St Petersburg Press, 2018), 352-97. ${ }^{39}$ A longer version of this discussion appears in “Cold War Binaries," 33-36. 
represent beds as a matter of primary necessity when they first moved in. When asked, "what did you buy first?," they reply, "a bed of course,".

The need for sleep seems so natural and essential that the equipment for it may also be taken for granted. Yet even regarding sleep, needs are culturally constructed, as comparison with other cultures shows, and are subject to change with time. ${ }^{40}$ Beds are not simply physical supports for sleeping but are imbricated in cultural practices, social relations and systems of meaning. Thus the bed and associated practices serve as a useful case study to track changing consumption behaviour.

The bed was identified as a prime target for modernization and rationalization in the Khrushchev era, resuming the 1920s campaign for the "new way of life" and "new person". Design and taste reformers were especially concerned to root out domestic practices of displaying wealth and status, and these included the treatment of the bed. In the traditional Russian and Tatar home, the bed - an iron frame with a mattress - would be set aside during the day as a permanent fixture in the room, the support for a display of wealth and good housekeeping, materialized in puffed-up feather pillows and fine white lace, known as shishki (cones). ${ }^{41}$

A number of my informants recall this practice of creating "show beds," and some (from rural backgrounds), such as Nina, a Russian, and Fatyma, a Tatar, both of whom moved to Kazan' from the countryside, still continued to make shishki in the mid 2000s. This treatment of the bed as a site for display of family wealth and the housewife's labour (embroidery, laundry, tidying, good housekeeping) was condemned in the late 1950s for its irrational waste of space and elevation of display over function, its un-socialist claims to status through material wealth, and its unreconstructed identification of women with bourgeois property relations and unproductive labour for the private home. ${ }^{42}$ The show bed became associated with the past, with petit-bourgeois values (meshchanstvo) and philistine bad taste, and with everything that was backward and rural; it was the antithesis of the modern, urban, socialist civilization, which the new flats and Contemporary Style were supposed to promote and represent.

\footnotetext{
40 Irene Cieraad, "Sleeping Around: the Bed from Antiquity to Now," Journal of Design History 20, no. 2 (2007): 177-78.

${ }^{41}$ Buchli, Archaeology: 88-9; Lidiia Chizhikova, "Zhilishche russkikh," in M. Rabinovich, ed., Material'naia kul'tura kompaktnykh etnicheskikh grupp na Ukraine (Moscow: Nauka, 1979).

42 Iu. V. Sharov, and G. G. Poliachek, Vkus nado vospytyvat' (Novosibirsk: Novosibirskoe knizhnoe izdatel'stvo, 1960); Stephen Harris, "Moving to the separate apartment: building, distributing, furnishing, and living in urban housing in Soviet Russia, 1950s1960s," PhD Diss. (University of Chicago, 2003): 529.
} 
A focus on domestic material culture, and conversations about it, reveals that in some ways citizens voluntarily espoused and sought to realize in their own homes the authoritative image of socialist modernity. In the modern furniture sets produced under the auspices of the Contemporary Style, the traditional iron bedstead was replaced by a low wooden divan, which could be used as a seat during the day. This displacement was rationalized as a response to the need to make efficient use of space, for all rooms in the flats were used for multiple purposes night and day. However, the purge of the bed as a permanent fixture in the room was also ideological, reflecting two principles which the Bolsheviks had shared with broader modernist tendencies: the rejection of nonfunctional, conventionalized display of prosperity; and the suppression of rest in favour of constant activity, wakefulness and mobility. In the 1920s, Constructivist (Productivist) artists had designed transformable furniture for the new active person; the suppression of sleep was marked by the fact that its equipment was hidden away during the day or converted into furniture for daytime, waking use. ${ }^{43}$ Resuming aspects of the earlier utopian campaign for physical as well as political mobilization, the modernizing specialists of the Khrushchev era set out to replace traditional styles of furniture by light, low and often multipurpose, convertible ones that made efficient, "rational" use of space and of materials.

\footnotetext{
43 Olga Matich, "Remaking the Bed: Utopia in Daily Life", in John E. Bowlt and Olga Matich, eds, Laboratory of Dreams (Stanford University Press, 1996), 59-78; Irene Cieraad, "A Nation under Reconstruction Never Sleeps: the Rise and Fall of the Dutch Wall Bed," Journal of Design History 18, no. 2 (2005), 167-77.
} 


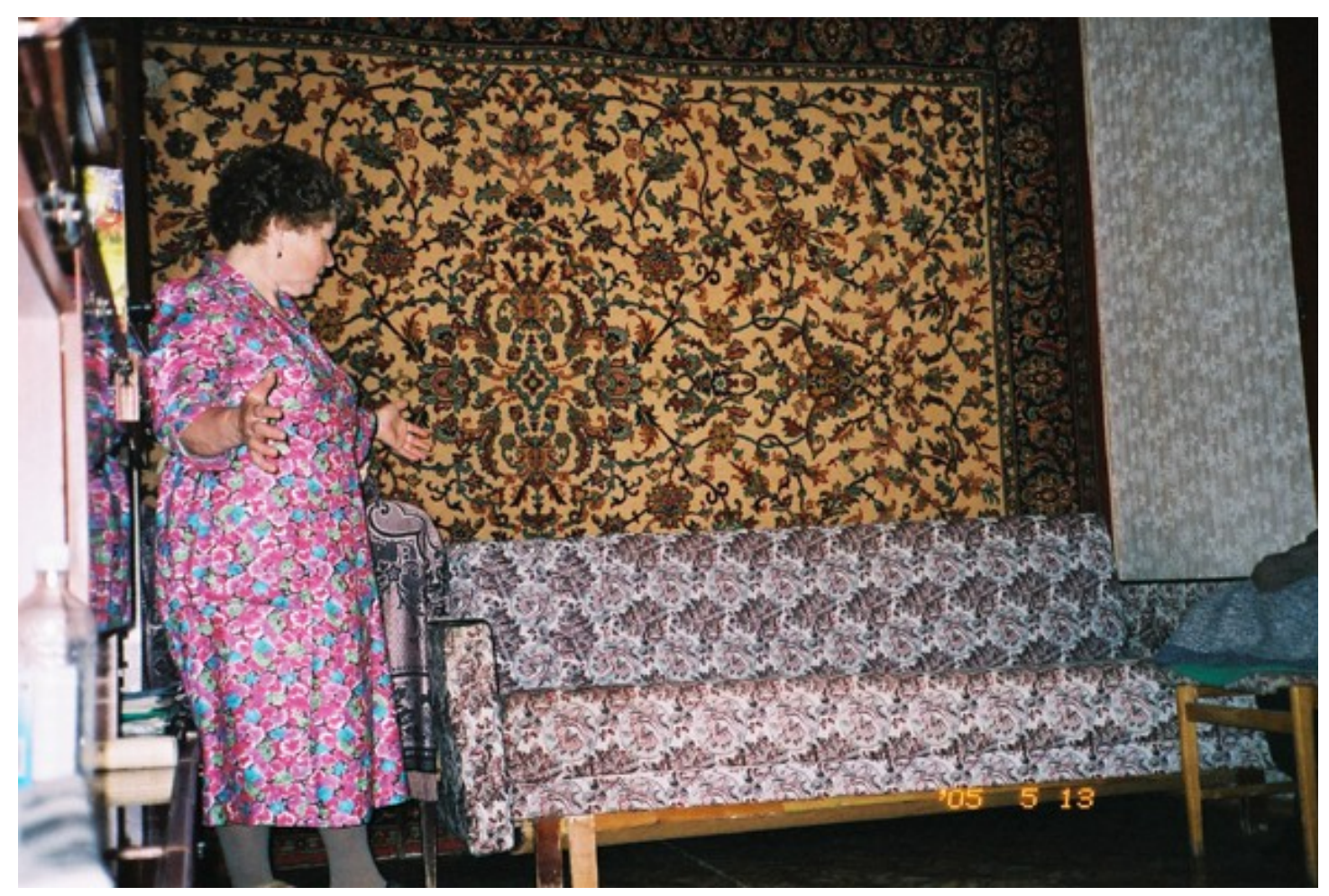

Fig 4. Roza's divan and rug. Photo for Everyday Aesthetics, 2005. Copyright: Susan E. Reid.

If my subjects had brought an old metal bedstead to the new apartment, many soon replaced it by the new furniture type. In the late 1950s, they had begun to discard metal bedsteads by choice in exchange for the modern furniture type serving the same function, the low-wooden divan that could be converted into a settee during the day. While the old beds continued to serve the physiological need of accommodating sleep, just as they always had, they no longer fulfilled cultural needs associated with "fashion" and with achieving a "contemporary" interior and modern lifestyle.

Nina - poor, provincial with little education - dismissed the notion of "fashion" in regard to her homemaking. With time, however, her spending power increased: "Somehow we got by. And we even managed to put away money in the [savings] book." Within a few years of her moving in in 1965, and just a few years after divans on wooden frames began to appear in the early 1960s, she also replaced the iron bed. The descent of her oncevalued metal bed down the career ladder of things was marked by its relegation from the urban apartment to the dacha (in other cases the bed was handed down to relatives in the countryside) and then being stolen for scrap metal.

Interviewer: "Why did you throw out the iron beds? Were they uncomfortable?" Nina: "No not because of that. Yes, of course, people already started to buy wooden ones. It [the bed] was already old. Then we took it to the [dacha] garden. And there it was stolen for the metal. [...] We moved in with a metal one. So it was metal. Some had 
[wooden divans] earlier. Those who were able to. Those who had money bought furniture. It was always in the shops.

Another, Mariia, also specifically cited changing fashion as a reason for replacing her old bedstead by the new type of divan: "We decided that beds were not fashionable." Leningrad teacher, Evgeniia, meanwhile picked up a bed on a dump. Someone else had thrown it out because they were already moving on to divans.

\section{Rugs}

Galina (born 1950, with higher education) describes from memory a typical traditional interior from her Leningrad childhood in the 1950s-60s: "On the wall was a rug - that was the done thing. It was thought that it was cold to sleep otherwise, or some such thing. There were also some pictures and photographs." ${ }^{44}$ In the traditional Russian and Tatar interior, the focal element was a large rug hung on the wall behind a divan. Rugs used in this way were condemned by modernist advice in the Khrushchev era as backwardlooking, unhygienic, oriental dust-catchers. Some of my informants concurred with this view. Yet rugs were still sought-after by almost all the homemakers in my study, as essential material of homeyness and markers of prosperity in accordance with traditional norms of proper homemaking [uiutnost'], still mandatory even when they moved to new prefabricated flats with their modern, industrial aesthetic. The interiors indicate the kinds of negotiations homemakers had to engage in. Rugs were a site of conflict among family members, between old and new consumption priorities and home-decorating practices. For example, Roza, a Tatar' woman living in Kazan', rejected the practice of hanging rugs on the wall, just as the authoritative prescriptions of contemporary good taste demanded. However, in spite of her own preference to adopt the modern, Contemporary Style, she had to hang rugs to accommodate her Dagestani mother-in law's criteria of a proper home. ${ }^{45}$

This exemplifies the limitations of considering only the top-down, specialist discourses available to historians in published and archival textual documents. A whole complex of factors interacted and met in people's domestic interiors, and homemakers confronted contradictory norms. The new dictates of good, modern taste in home decorating

\footnotetext{
44 Galina, St Petersburg, interviewed 2007 for "Everyday Aesthetics".

45 Susan E. Reid, "This is Tomorrow: Becoming a Consumer in the Soviet Sixties," in Anne E. Gorsuch and Diane Koenker (eds), The Socialist Sixties: Crossing Borders in the Second World (Bloomington, IN: Indiana University Press, 2013), 25-65.
} 
prescribed a radical renewal of domestic material culture. ${ }^{46}$ But for homemakers it was not so simple; they had to negotiate between the new norms and material structures, their own material possibilities, and their unconsciously acquired dispositions and assumptions about homeyness, propriety and taste. They also had to accommodate the strictures of other authorities, closer to hand than the abstract experts, concerning propriety and "how it is done". ${ }^{47}$ Many spoke of familial, intergenerational contentions over the aesthetics of the home, consumption priorities, and markers of household identity and prosperity, and of how they had to accommodate their own desire for a modern interior with the preferences and notions of propriety of the older generation (often sharing the same roof, despite the principle of nuclear family allocation). ${ }^{48}$ In practice, the modernizing vertical authority of party and specialists had to compete with the conservative social authority of the older generation. 49

\section{Photographs as material culture}

In addition to rugs, there were further negotiations to be made concerning the choice of what to hang on one's walls and how to hang it. ${ }^{50}$ Photographs, along with other pictures in domestic interiors, should be considered not only as images, but as material objects and sets of practices. ${ }^{51}$ Photographic display practices emerge from the evidence of the apartment walls and the interviews as a matter of significance and anxiety to my informants in relation to social distinctions and a changing sense of self. They materialize diachronic and synchronic, self-other relations in terms of sameness or difference. Even

${ }^{46}$ E.g. I. Odintsova, "Veshchi v nashem bytu," Sovetskaia torgovlia, no. 7 (1961): 51 of 513.

47 Pierre Bourdieu, The Logic of Practice (Stanford, CA: Stanford University Press, 1980); Reid, "Communist Comfort"; Joseph S. Berliner, Foreword, in James R. Millar, ed., Politics, Work and Daily Life in the USSR: A Survey of Former Soviet Citizens (Cambridge: Cambridge University Press, 1987), x.

${ }^{48}$ Analysing similar conditions under late socialism in Slovakia, Makovicky denies that choice played any part for her informants, or that aesthetic choices in the home were a matter of negotiation. Makovicky, "Closet," 2007.

${ }^{49}$ Stephen Lovell, "Soviet Russia's Older Generations," in idem, ed. Generations in Twentieth-Century Europe (Houndsmill: Palgrave Macmillan, 2007), 205-226.

${ }^{50} \mathrm{An}$ earlier version of this discussion appears in Russian translation in Susan E. Reid, "Kak obzhivalis' v pozdnesovetskoi modernosti" ["Making Oneself at Home in Late Soviet Modernity"], in A. Pinsky, ed., Posle Stalina: pozdnesovetskaia sub"ektivnost', 1953-1985 gg. [After Stalin: Subjectivity in the Late Soviet Union, 1953-1985] (St Petersburg Press, 2018), 352-97.

${ }^{51}$ Elizabeth Edwards and Janice Hart, eds, Photographs, Objects, Histories: on the Materiality of Images (London: Routledge, 2004); cf. Rebecca Empson, Harnessing Fortune: Personhood, Memory, and Place in Mongolia (Oxford: Oxford University Press, 2011). 
as their content--portraits of family members, dead and alive--was directed at continuity and preservation of memory, ${ }^{52}$ photographic displays also mark changes through time.

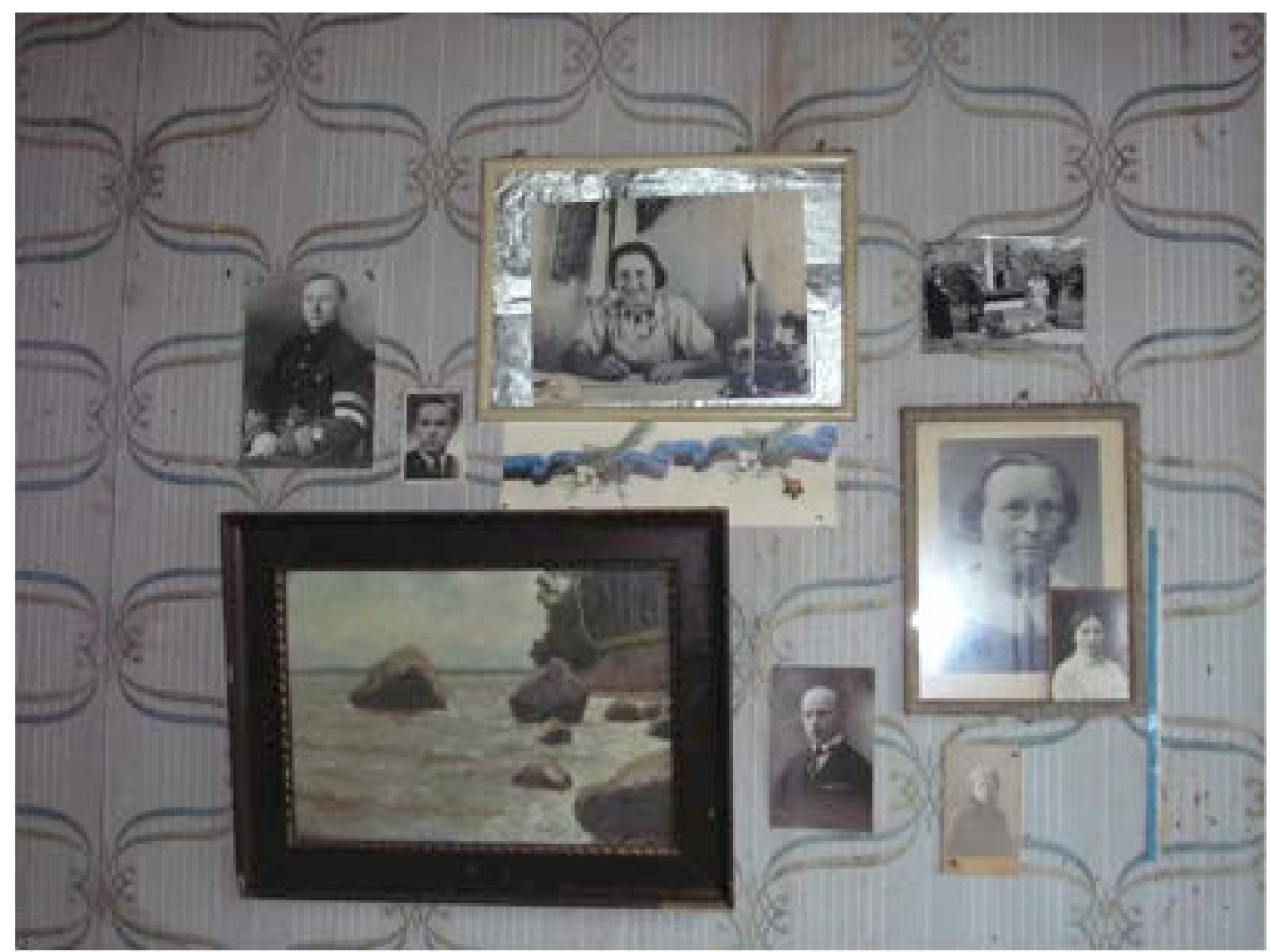

Fig. 5. Few wall displays of family photographs were still extant by the time of the interviews, having become unfashionable in the 1960s-70s. Photo: Tartu, 2005, for Everyday Aesthetics, 2005. Copyright: Susan E. Reid

My oldest informants recalled that it was "fashionable," in their lifetime, to have photographic collages or oklady (iconostases): arrangements of a large number of framed family photographs on the wall, sometimes contained within a rectangular frame. Anna F. (Kovdor), born in 1919, had left her impoverished village in the South West of Russia when she was eighteen years old to move to the Far North in search of income, selfbetterment and opportunity, and she had trained as an aircraft engineer. In the mid2000s she still had photos of family members on the wall, hung in frames that her husband had made. Raisa (Kaluga) also came from a very poor rural background, but was a generation younger than Anna F. She recalls that photographs of family - grandparents, aunts, parents - mounted on card or board, in wooden frames of different sizes, had been "fashionable" in the post-war period. However, some time before 1968 they had

52 Elizabeth Edwards, "Photographs as Objects of Memory" in Kwint et al., eds, Material Memories, 221 of 221-236. 
"suddenly disappeared". ${ }^{53}$ Similarly, Zinaida (Kovdor) associated the practice of hanging photographs with her childhood home where she remembered "oklady" (iconostases) of photos on the wall. As an adult this was something she never practiced, she emphasizes; it had no part in her homemaking or her self-construction.

Zinaida: I never hung photos. Although when I was a child we had these big oklady and all the photos were there on the wall.

Interviewer: But you didn't want to do it here?

Z: No.

I: You didn't like it? Why?

Z: I don't know. Evidently things had changed, so to speak... it was mother's apartment. Well, how to put it, everybody had them and clearly everyone imitated one another. I don't know. Here we didn't. We didn't hang any pictures at all.

As in the case of beds, Zinaida and others explain the disappearance of foto-oklady in terms of "fashion," implying that it was a matter of imitation of others. ${ }^{54}$ Some of my St. Petersburg intelligentsia informants, such as Anna A. had no photos on the walls. "There were definitely never any photos. (...) Somehow it wasn't done [to put them] on the walls."

Interviewer: So why weren't there any photos? In your family back when you lived in Orenburg, did you have photos?

Anna: Never, never.

Anna's daughter: Well it depends on the family.

I: Because in a lot of people's [homes] they've kept whole iconostases.

A: Well you know, no. [...] I remember of course that on the buffet there were very fine frames. There were photos there, I suppose, of father

Daughter: they were displayed...

A: But never on the walls.

Conscious of their cultural capital and the cultured, modern tastes this presupposed, Anna and her daughter make clear the social stigma attached to display practices: putting photos on the wall was the kind of thing that other people did--those who also hung rugs on the wall; it was a lower class or "rural" practice and, as such, backward and old fashioned. ${ }^{55}$ Asked why she did not hang photos on the walls, Tat'iana, who had moved to the city of Kaluga from a village, replied unequivocally: "That's in the countryside; there were my mother's photos hanging there. She came here, my mum died here, and I left the photograph of her, of course, but I hung it in my own bedroom, my own. I didn't hang anything in the girls' room." Rejecting the practice, she separated herself from her rural mother and from her own rural origins, thus shoring up her sense of herself as a modern urban dweller. To hang photos was a rural practice and, she says, "after all, it's the city

\footnotetext{
53 Tat'iana, Kovdor, interviewed 2007 for "Everyday Aesthetics".

${ }^{54}$ Svetlana in Apatity, interviewed 2007 for "Everyday Aesthetics," also explains the passing of this practice in the same way.

${ }^{55}$ Cf. Leonid Nevler, “Vse gorazdo slozhnee...” DI SSSR, no. 3 (1963): 29-32.
} 
here." Thus, the material culture of photographic display emerges as a divider between past and present selves and between self and others, along generational and urban/rural lines, as well as those of class and education. The ways they discuss their own and other people's aesthetic and consumption decisions indicates a strong sense of hierarchical stratification or distinction on the basis of cultural capital.

Given the close connection between photos, memory and self-identity, Tat'iana's account also suggests another process at work. This was not so much to do with large categories such as class, as the basis of identity, but more with personal relationships and a subjective sense of self. The single photograph of her mother, which survived this purge, now hung in her personal space, the bedroom. The iconostasis of photos that had once hung on the walls of the household's shared space, the zal (parlour), had laid out family identity in terms of genealogy and generations for all who lived there and their visitors to see. With its removal, the "public" display of dynasty, defining who one is through heredity, one's relations to past generations, was replaced by a more selective, immediate and intimate display of a single photo of her mother, which migrated to the more "private" space of her bedroom. In other cases, photos were kept, unframed, behind the glazed doors of the cabinet, to be taken out occasionally, shown and held. ${ }^{56}$ The disappearance of the family tree from the wall coincided approximately with the period of moving to new flats designed for single nuclear families, and its consequences: the separation (in some cases) from the older generation, loosening hold of tradition, and purge of old material culture. ${ }^{57}$

\section{Conclusion}

Why then should material culture matter to the historian of Khrushchev-era Soviet Union? First, enormous significance and agency were ascribed in the Khrushchev era to material conditions in the project of social transformation. While textual sources (contemporary publications and archival sources) can tell us much about these authoritative positions and intentions, they are less informative about how it was

\footnotetext{
${ }^{56}$ E.g. Anneta, Kaluga, takes out her "nenagliadnaia" (beloved), an old photo-postcard of Brigitte Bardot, to show the interviewer.

57 Photographs, once a prestigious luxury commodity, became commonplace, part of mass visual culture. Igor' Narskii, Fotokartochka na pamiat': semeinye istorii. Fotograficheskie poslaniia i sovetskoe detstvo (Cheliabinsk: Entsiklopediia, 2008). See also V. Shlapentokh, Public and Private Life of the Soviet People: Changing Values in Post-Stalin Russia (Oxford University Press, 1989); Aralovets, Gorodskaia sem"ia v Rossii, 1927-1959 gg. (Tula: Grif i K, 2009), 228-9; Kent Geiger, "The Family and Social Change," in Cyril Black, ed., The Transformation of Russian Society: Aspects of Social Change Since 1861 (Harvard University Press, 1960), 447-58.
} 
realized on the ground. Domestic material culture and the way occupants of state housing negotiated domestic architectural space can be a useful prism to study both micro and macro within the same frame. Material culture, as a historical source, and material culture history as a methodology, can help us access aspects of popular agency in and experience of this period of intensive modernization and transformation of the material environment. In combination with other types of sources, material culture can allow us a glimpse of how the intensive modernization that took place in the Soviet Union after Stalin was experienced but also produced in everyday life, and can help us to understand the meanings which this process had in "ordinary people's" lives and in their sense of self. It can help us to reach a more nuanced understanding of the nature of Soviet "consumer society" as it was lived (including ways in which it departs from the dominant model of modern consumer society based on an idealized image of US consumption). Material culture - taken in combination with how subjects talk about it - allows us insights into self-ascribed identities and social distinctions (class) on grounds of taste and preferences in home decorating and consumption. It can help us to draw out how people felt about themselves, their relations to others, aspirations and social mobility, for example, the changes associated with the move from countryside to the city. It also allows us to complexify the idealized picture presented by authoritative contemporaneous sources: to trace the tensions, between forces of continuity and change; the contradictions between different authorities and macro "structures"; as well as the emergence of new attitudes towards consumption, and new identities. It takes us away from questions about how change was supposed to happen and prescriptions for how people should embrace modernity, towards understanding how, in everyday practice, they struggled with the relations between old and new material culture, and how they appropriated or accommodated the material givens of their lives. 